\title{
PENGARUH MODEL PEMBELAJARAN COOPERATIVE INTEGRATED READING AND COMPOSITION BERBANTUAN MEDIA CERITA BERGAMBAR TERHADAP KEMAMPUAN MEMBACA DAN HASIL MEMBACA PEMAHAMAN SISWA KELAS IV
}

\author{
K.E. Mariadeni ${ }^{1}$, N. K. Suarni ${ }^{2}$, I. B. Putrayasa ${ }^{3}$ \\ Program Studi Pendidikan Dasar, Program Pascasarjana \\ Universitas Pendidikan Ganesha \\ Singaraja, Indonesia \\ e-mail: mariadenieli@gmail.com ,. \\ ketut.suarni@pasca.undiksha.ac.id, bagus.putrayasa@pasca.undiksha.ac.id
}

\begin{abstract}
Abstrak
Penelitian ini bertujuan, 1) untuk mengetahui perbedaan kemampuan membaca antara siswa yang mengikuti model pembelajaran CIRC berbantuan media cerita bergambar dengan model pembelajaran konvesional, 2) untuk mengetahui perbedaan hasil membaca pemahaman antara siswa yang mengikuti model pembelajaran CIRC berbantuan media cerita bergambar dengan model pembelajaran konvesional, 3) untuk mengetahui secara simultan perbedaan kemampuan membaca dan hasil membaca pemahaman antara siswa yang mengikuti model pembelajaran CIRC berbantuan media cerita bergambar dan siswa yang mengikuti model pembelajaran konvesional. Penelitian ini merupakan quasi eksperimen dengan rancangan Single Factor Independent Group Design. Populasi penelitian seluruh kelas IV SD, sampel berjumlah 65 siswa. Penetapan sampel dengan teknik random sampling. Pengumpulan data menggunakan lembar observasi dan tes bentuk objektif. Data yang diperoleh dianalisis menggunakan uji MANOVA. Hasil penelitian menghasilkan, 1) terdapat perbedaan kemampuan membaca siswa yang mengikuti pembelajaran dengan model pembelajaran CIRC berbantuan cerita bergambar dengan siswa yang mengikuti pembelajaran konvensional, 2) terdapat perbedaan hasil membaca pemahaman siswa yang mengikuti pembelajaran dengan model pembelajaran CIRC berbantuan cerita bergambar dengan siswa yang mengikuti pembelajaran konvensional, 3) secara simultan terdapat perbedaan kemampuan membaca dan hasil membaca pemahaman antara siswa yang mengikuti pembelajaran dengan model pembelajaran CIRC berbantuan cerita bergambar dengan pembelajaran konvensional.
\end{abstract}

Kata kunci: Kemampuan Membaca, Membaca Pemahaman, CIRC

\begin{abstract}
This research aims determine 1) to learn the difference in reading skills between students using the CIRC learning model assisted with illustrated story media with conventional learning models, 2) to learn to understand learning outcomes between students using CIRC learning models assisted with illustrated story media with conventional learning models, 3) for models CIRC learning is supported by pictorial story media and students who follow conventional learning models. This research was quasiexperimental study with the design of Single Factor Independent Group Design. The population of this were fourth grade elementary school, a sample of 65 students. Sample selection by random sampling technique. Data collection used observation sheet and objective form test. The data obtained were analyzed using MANOVA test. The result 1) differences in the reading skills students who attend learning model Cooperative Integrated Reading and Compotition assisted by picture story media with students who follow learning conventional, 2) differences in reading comprehension results students who attend learning model Cooperative Integrated Reading and Compotition assisted by picture story with students who follow learning conventional, 3) simultaneously are differences in reading skills and reading comprehension results between students who attend learning model Cooperative Integrated Reading and Compotition assisted by picture story with learning conventional.
\end{abstract}

Keywords: Reading Skill, Reading Comprehension, CIRC 


\section{PENDAHULUAN}

Pendidikan mempunyai peran yang sangat penting dalam meningkatkan kualitas sumber daya manusia dan upaya mewujudkan cita-cita bangsa Indonesia untuk mewujudkan kesejahteraan umum dan mencerdaskan kehidupan bangsa. Oleh karena itu, pendidikan bagi kehidupan umat manusia merupakan kebutuhan yang dipenuhi sepanjang hayat. Menurut Undang-Undang Republik Indonesia Nomor 20 Tahun 2003 tentang Sistem Pendidikan Nasional (SISDIKNAS) Bab II Pasal 3 disebutkan bahwa,

"Pendidikan nasional berfungsi mengembangkan kemampuan dan membentuk watak serta peradaban bangsa yang bermartabat dalam rangka mencerdaskan kehidupan bangsa, bertujuan untuk berkembangnya potensi peserta didik agar menjadi manusia beriman bertakwa kepada Tuhan Yang Maha Esa, berakhlak mulia, sehat, berilmu, cakap, kreatif, mandiri, dan menjadi warga Negara yang demokratis serta bertanggung jawab".

Melalui pendidikan yang layak, diharapkan akan terbentuk manusia Indonesia yang berkualitas dan dapat bersaing di dunia global. Dalam menunjang perbaikan pendidikan sangat dibutuhkan peran seorang pendidik. menciptakan suasana yang menumbuhkan semangat belajar memerlukan proses belajar yang baik untuk menjadikan peserta didik sebagai pusat dalam kegiatan belajar. Dengan demikian pembelaran akan menjadi semakin efektif dan mampu menciptakan suasana belajar yang kondusif sehingga menjadi titik awal peningktan hasil belajar siswa. Sekolah sebagai lembaga pendidikan formal merupakan organisasi dengan kegiatan utama mengelola pendidikan, harus bertanggungjawab dalam mengembangkan kompetensi belajar siswa untuk dapat dikembangkan dengan lebih terarah sesuai dengan spesifikasi tertentu melalui proses pembelajaran yang lebih inovatif. Oleh karena itu, proses pembelajaran di sekolah harus dikelola secara efektif dan efisien, agar dapat menghasilkan sejumlah lulusan (output) yang memiliki kompetensi, adaptif dan kompetitif.

Undang undang nomor 20 tahun 2003 sudah menyebutkan beberapa pesebaran mata pelajaran yang ada di sekolah dasar diantaranya adalah bahasa Indonesia. Pembelajaran Bahasa Indonesia merupakan pembelajaran yang mencakup seluruh aspek kebahasaan yang membelajarkan siswa untuk berkomunikasi dengan baik dan benar, baik secara lisan maupun secara tulisan. Pada dasarnya pembelajaran Bahasa Indonesia adalah belajar menggunakan bahasa yang baik dan benar, selain itu pembelajaran bahasa Indonesia berorientasi pada aspek keterampilan menyimak, membaca, menulis dan berbicara. Keempat aspek keterampilan bahasa tersebut saling berhubungan satu sama lain. Pembelajaran bahasa Indonesia di sekolah, keempat aspek tersebut mendapat posisi yang seimbang dan dilaksanakan secara terpadu.

Hasil observasi menunjukkan bahwa ada permasalahan dalam proses pembelajaran bahasa. Permasalahan ini muncul karena guru masih menggunakan pembelajaran konvensional dalam kegiatan pembelajaran bahasa Indonesia. Guru mendominasi pembelajaran dengan melakukan metode ceramah dan penugasan yang membuat siswa kurang aktif dan merasa bosan dalam proses pembelajaran. Dalam menyampaikan materi pelajaran guru juga jarang menggunakan media yang sesuai dengan tema pembelajaran yang membuat pembelajaran kurang menarik minat siswa dalam mengikuti pelajaran sehingga keterampilan membaca belum mampu mencapai hasil yang optimal. Pembelajaran Bahasa Indonesia masih berorientasi pada guru dan kurang memberi pemahaman dengan jelas kepada siswa tentang materi pembelajaran.

Selain itu, di SD Gugus VI Kecamatan Buleleng yang akan menjadi tempat penelitian. Berdasarkan data studi dokumentasi hasil tes akhir semester I 
siswa kelas IV SD Gugus VI Kecamatan Buleleng tahun pelajaran 2018/2019 khususnya pada mata pelajaran bahasa indonesia bahwa rata-rata hasil tes akhir semester satu matematika kelas IV Gugus VI Kecamatan Buleleng ditemukan hasil ulangan siswa masih dibawah KKM. Melihat hasil belajar yang masih rendah seperti maka harus dicari akar penyebabnya. Kesenjangan yang terjadi antara upaya dan kenyataan disebabkan oleh beberapa faktor yang mengakibatkan menurunnya kualitas pendidikan. Salah satu isu yang paling penting dalam pengembangan kualitas pendidikan adalah adanya peran guru dalam mengaplikasikan model pembelajaran di kelas yang kurang menekankan kemampuan membaca siswa yang menyebabkan hasil belajar siswa masih kurang.

Membaca merupakan perbuatan yang dilakukan berdasarkan kerjasama beberapa keterampilan, yakni mengamati, memahami, dan memikirkan (Burhan dalam Slamet 2015). Kemampuan membaca adalah dapat memahami fungsi dan makna yang dibaca, dengan cara mengucapkan bahasa, mengenal bentuk, memahami isi yang dibaca. Adapun kemampuan membaca yang dimaksud dalam penulisan ini adalah merupakan suatu proses pemahaman tentang isi bacaan dengan kegiatan mencocokan huruf atau melafalkan lambang-lambang bahasa tulis sehingga dapat memahami apa isi bacaan tersebut.

Membaca pemahaman adalah pemahaman arti atau maksud dalam suatu bacaan melalui tulisan. Definisi ini sangat menekankan pada dua hal yang pokok dalam membaca, yaitu bahasa itu sendiri dan simbol grafik tulisan yang menyajikan informasi yang berwujud bacaan (Nurhadi dalam Sumira, dkk. 2017). Jadi, seseorang yang melakukan kegiatan membaca pemahaman harus menguasai bahasa atau tulisan yang digunakan dalam bacaan yang dibacanya dan mampu menangkap informasi atau isi bacaan tersebut.

Hal tersebut akan berdampak pada rendahnya kemampuan membaca dan hasil membaca pemahaman siswa. Oleh karena itu, diperlukan suatu pengemasan pembelajaran yang mampu menumbuhkan kemampuan membaca dan meningkatkan hasil membaca pemahaman siswa. Salah satu model pembelajaran inovatif yang dipandang tepat untuk digunakan adalah model pembelajaran CIRC (Cooperative Integrated Reading and Composition). Model pembelajaran ini untuk meningkatkan kemampuan membaca siswa terhadap suatu wacana yang disediakan guru. CIRC (Cooperative Integrated Reading and Composition) adalah suatu model dalam pembelajaran kooperatif yang digunakan bagi guru unuk mengajar siswa.

$$
\text { Model pembelajaran CIRC }
$$

(Cooperative Integrated Reading and Composition) merupakan kurikulum komprehensif yang dirancang untuk digunakan dalam pelajaran membaca pada kelas 2-8 (Slavin, 2008). Selain itu CIRC (Cooperative Integrated Reading and Composition) merupakan program pembelajaran komprehensif untuk mengajarkan membaca dan menulis pada siswa kelas dasar pada tingkat yang lebih tinggi dan juga pada sekolah menengah (Slavin, 2008). Menurut Kautsar (2017) Model CIRC (Cooperative Integrated Reading and Composition) adalah model pembelajaran kooperatif yang digunakan dalam pembelajaran bahasa, yakni kemampuan membaca dan menulis tingkat tinggi. Model pembelajaran CIRC (Cooperative Integrated Reading and Composition) ini termasuk dalam Cooperative Learning dimana dalam pembelajaran ini akan tercipta sebuah interaksi yang lebih luas, yaitu interaksi dankomunikasi yang dilakukan antara guru dengan siswa, siswa dengan siswa, dan siswa dengan guru. Hal ini diharapkan dapat berguna bagi siswa dalam menjalani kehidupan sehari-hari dan menjadi pribadi cerdas dan unggul. Pada proses pembelajaran jika pemanfaatan model ini dipadukan dengan penggunaan media cerita bergambar maka dapat membuat siswa lebih aktif dalam mengemukakan gagasan pokok yang ada dalam alur cerita tersebut. Melalui cerita bergambar siswa 
mampu mengamati dan menemukan gagasan pokok yang terkandung dalam cerita secara detail.

Berdasarkan penelitian yang

dilakukan oleh 1) Penelitian $\mathrm{Ni}$ Made

Yudasmini tahun 2015 dengan judul

"Pengaruh Model Pembelajaran CIRC

(Cooperative Integrated Reading And

Composition) terhadap Minat Baca dan

Kemampuan Memahami Bacaan pada

Siswa Kelas VI Di Sekolah Dasar Gugus

Buruan". Adanya perbedaan yang signifikan

menunjukkan bahwa Model pembelajaran

Model Pembelajaran CIRC (Cooperative

Integrated Reading And Composition)

berpengaruh secara signifikan terhadap

minat baca dan kemampuan memahami

bacaan pada siswa kelas VI Di Sekolah

Dasar Gugus Buruan. Peneliti menemukan adanya peningkatan minat membaca dan kemampuan memahami bacaan, 2) Penelitian Luh Sandiyani tahun 2016 dengan judul "Pengaruh Model Pembelajaran CIRC (Cooperative Integrated Reading And Composition) Berbantuan Cerita Pendek Terhadap Keterampilan Membaca Pemahaman". Hal ini ditunjukkan dari hasil penelitian, bahwa ada perbedaan yang signifikan keterampilan membaca pemahaman antara kelompok siswa yang belajar menggunakan model pembelajaran CIRC (Cooperative Integrated Reading and Composition) dengan kelompok siswa yang belajar menggunakan model pembelajaran konvensional. Kelompok siswa yang belajar menggunakan model pembelajaran CIRC (Cooperative Integrated Reading and Composition) lebih terlihat hasil membaca pemahaman yang baik, 3) Penelitian Ni Putu Yuni Setiawati tahun 2017 dengan judul "Pengaruh Model Pembelajaran CIRC Berbasis Tulisan Eksposisi Terhadap Kemampuan Membaca Intensif Siswa Kelas IV". Hal ini ditunjukkan dari hasil penelitian, bahwa ada perbedaan yang signifikan kemampuan membaca intensif antara kelompok siswa yang belajar menggunakan metode pembelajaran CIRC (Cooperative Integrated Reading and Composition) dengan kelompok siswa yang belajar menggunakan model pembelajaran konvensional. Kelompok siswa yang belajar menggunakan model pembelajaran CIRC (Cooperative Integrated Reading and Composition) lebih terlihat kemampuan membaca yang baik. Berdasarkan beberapa hasil penelitian tersebut, tampak bahwa model pembelajaran CIRC (Cooperative Integrated Reading and Composition) memberikan dampak positif terhadap variabel-variabel yang dipengaruhi.

Berdasarkan masalah di atas maka dapat di rumuskan permasalahan sebagai berikut.

1) Apakah terdapat perbedaan kemampuan membaca antara siswa yang mengikuti model pembelajaran CIRC (Cooperative Integrated Reading and Composition) Berbantuan Cerita Bergambar dengan model pembelajaran konvesional pada siswa kelas IV di Sekolah Dasar Gugus VI Kecamatan Buleleng?

2) Apakah terdapat perbedaan hasil membaca pemahaman antara siswa yang mengikuti model pembelajaran CIRC (Cooperative Integrated Reading and Composition) Berbantuan Cerita Bergambar dengan model pembelajaran konvesional pada siswa kelas IV di Sekolah Dasar Gugus VI Kecamatan Buleleng?

3) Apakah terdapat perbedaan simultan Kemampuan membaca dan hasil membaca pemahaman antara siswa yang mengikuti model pembelajaran CIRC (Cooperative Integrated Reading and Composition) Berbantuan Media Cerita Bergambar dengan siswa yang mengikuti model pembelajaran konvesional pada siswa kelas IV di Sekolah Dasar Gugus VI Kecamatan Buleleng?

Berdasarkan uraian di atas, penelitian ini hendak mengangkat masalah melalui suatu penelitian eksperimen dengan menerapkan salah satu model pembelajaran dengan judul "Pengaruh Model Pembelajaran CIRC (Cooperative Integrated Reading and Composition) 
Terhadap Kemampuan Membaca dan Hasil Membaca Pemahaman Siswa Kelas IV SD.

\section{METODE}

Jenis eksperimen pada penelitian ini yaitu eksperimen semu (quasi eksperiment). Penelitian ini dilakukan untuk mengetahui pengaruh model pembelajaran CIRC (Cooperative Integrated Reading and Composition) terhadap kemampuan membaca dan hasil membaca pemahaman siswa kelas IV. Dengan demikian rancangan analisis data penelitian yang digunakan adalah single factor independent groups design (Dantes,2017). Populasi dalam penelitian ini adalah semua siswa kelas IV SD N Gugus VI Kecamatan Buleleng yang berjumlah 155 orang yang terdistribusi ke dalam kelas-kelas homogen secara akademik. Pembagian kelas yang ada ini tidak didasarkan peringkat, sehingga siswa yang memiliki prestasi tinggi tersebar dalam setiap kelas. Pengambilan sampel dilakukan dengan teknik random sampling. Teknik random sampling ini digunakan karena anggota populasi relatif homogen (Sugiyono, 2010). Sampel yang diperoleh dengan teknik random sampling dinilai mantap karena memiliki tingkat kerepresentatifan tinggi yang mewakili populasinya. Berdasarkan teknik random sampling yang dilakukan, maka terpilih SD Negeri 3 Kampung Baru yang dikenai perlakuan model pembelajaran CIRC (Cooperative Integrated Reading and Composition) sedangkan SD Negeri 1 Kampung Baru yang dikenai perlakuan model pembelajaran konvensional. Datadata yang dikumpulkan dalam penelitian ini adalah kemampuan membaca dan hasil membaca pemahaman. Data hasil membaca pemahaman siswa dikumpulkan dengan tes objektif sebanyak 30 butir soal berbentuk pilihan ganda. Data kemampuan membaca siswa dikumpulkan dengan tes lembar observasi.

Data dianalisis secara deskriptif dan Multivariat Analysis of Varian (MANOVA). Analisis deskriptif digunakan untuk dapat mendeskripsikan nilai rata-rata siswa, simpangan baku pemahaman konsep, dan sikap ilmiah siswa. Pengujian hipotesis penelitian ini menggunakan MANOVA satu jalur. Sebelum pengujian hipotesis, terlebih dulu dilakukan uji normalitas sebaran data dengan menggunakan statistik Kolmogorov-Smirnov dan Shapiro-Wilk, uji homogenitas varian antar kelompok menggunakan Levene's Test of Equality of Error Variance, uji homogenitas matrik varian antar kelompok menggunakan uji Box's $M$, dan uji kolinieritas variabel terikat menggunakan uji korelasi Product Moment. Uji komparasi signifikansi nilai rata-rata menggunakan Least Significant Difference. Semua pengujian hipotesis dilakukan pada taraf signifikansi 0,05 yang dianalisis dengan bantuan program SPSS 17.0 PC for Windows dan Microsoft Excel 2007.

\section{HASIL DAN PEMBAHASAN Hasil}

Deskripsi umum hasil penelitian yang dipaparkan pada bagian ini adalah deskripsi nilai kemampuan membaca dan hasil membaca pemahaman siswa pada Tabel 1.

Tabel 1 Rekapitulasi Hasil Perhitungan Skor Kemampuan Membaca dan Hasil Membaca Pemahaman

\begin{tabular}{|c|c|c|c|c|}
\hline \multirow{2}{*}{ Statistik } & \multicolumn{4}{|c|}{ Kemampuan Membaca } \\
\cline { 2 - 5 } & Mean & Median & Modus & $\begin{array}{c}\text { Standar } \\
\text { Deviasi }\end{array}$ \\
\hline Model CIRC & 48,6 & 49 & 47 & 5,15 \\
\hline $\begin{array}{l}\text { Model } \\
\text { konvensional }\end{array}$ & 38,64 & 39 & 45 & 4,40 \\
\hline \multicolumn{4}{|c|}{ Statistik } & \multicolumn{4}{|c|}{ Hasil Membaca Pemahaman } \\
\cline { 2 - 5 } & Mean & Median & Modus & $\begin{array}{c}\text { Standar } \\
\text { Deviasi }\end{array}$ \\
\hline Model CIRC & 23,12 & 23 & 19 & 2,09 \\
\hline $\begin{array}{l}\text { Model } \\
\text { konvensional }\end{array}$ & 17,23 & 17 & 17 & 1,95 \\
\hline
\end{tabular}


Pada Tabel 1, tampak bahwa kelas ekperimen yang mendapat perlakuan dengan model pembelajaran CIRC (Cooperative Integrated Reading and Composition) menunjukkan pencapaian kemampuan membaca dan hasil membaca pemahaman lebih baik dibandingkan dengan kelas kontrol yang mendapat perlakuan model konvensional.

Hasil pengujian normalitas data menggunakan statistik KolmogiorovSmirnov dan Shapiro-Wilk menunjukkan bahwa nilai-nilai statistik yang diperoleh memiliki angka signifikansi lebih besar dari 0.05. Hal ini menunjukkan bahwa sebaran data kemampuan membaca dan hasil membaca pemahaman siswa berdistribusi normal. Hasil pengujian homogenitas varian mengunakan Levene's Test of Equality of Error Variances untuk kelompok model pembelajaran menunjukkan angka-angka signifikansi statistik Levene lebih besar dari $\alpha=0,05$. Hal ini menunjukkan bahwa varian antar model pembelajaran adalah homogen. Hasil pengujian homogenitas matrik varian menggunakan uji Box's $M$ menunjukkan bahwa Box's $M$ memiliki nilai 1,977 dengan $\alpha=0,592$ dan lebih besar dari 0,05. Hal ini menunjukkan bahwa matriks varian variabel terikat adalah sama. Hasil pengujian korelasi antar variable terikat diperoleh nilai VIF (variance inflation factors) dari variabel tersebut besarnya 1 sehingga nilai tolerance $=1$. Berdasarkan hasil uji VIF, ternyata nilai VIF sama dengan 1 dan bila dilihat dari nilai tolerance $=1$, berdasarkan data di atas, dengan $\mathrm{VIF}=1 /$ tolerance maka variabel tersebut tidak mengalami multikolineritas. Karena uji prasyarat untuk sebaran data kemampuan membaca dan hasil membaca pemahaman, normal, varian antar model pembelajaran adalah homogen, matriks varian variabel terikat adalah sama, dan variabel keterampilan kemampuan membaca dan hasil membaca pemahaman tidak kolinear, maka uji MANOVA dapat dilanjutkan. Berdasarkan hasil analisis, didapatkan hasil seperti yang tersaji pada Tabel 2 berikut.
Tabel 2 Hasil Pengujian hipotesis

\begin{tabular}{|l|c|}
\hline \multicolumn{1}{|c|}{ Hipotesis } & Hasil analisis \\
\hline Hipotesis 1 & $(\mathrm{F}=98,97 ; \mathrm{p}<0,05)$ \\
\hline Hipotesis 2 & $(\mathrm{F}=142,47 ; \mathrm{p}<0,05)$ \\
\hline Hipotesis 3 & $(\mathrm{F}=142,47 ; \mathrm{p}<0,05)$ \\
\hline
\end{tabular}

Secara deskripsi Tabel 2 dapat dijelaskan sebagai berikut. untuk pengujian hipotesis pertama terdapat perbedaan kemampuan membaca antara siswa yang mengikuti model pembelajaran CIRC (Cooperative Integrated Reading and Composition) dengan siswa yang mengikuti model pembelajaran konvensional dengan rekapitulasi data $(F=98,97 ; p<0,05)$. Hasil ini berarti terdapat perbedaan kemampuan membaca antara siswa yang mengikuti model pembelajaran CIRC (Cooperative Integrated Reading and Composition) dengan siswa yang mengikuti model pembelajaran konvensional. Hipotesis kedua dalam penelitian ini adalah terdapat perbedaan hasil membaca pemahaman antara siswa yang mengikuti model pembelajaran CIRC (Cooperative Integrated Reading and Composition) siswa yang mengikuti model pembelajaran konvensional. Berdasarkan rekapitulasi hasil test of between-subjects effects dapat diinterpretasikan bahwa harga statistik $F$ sebesar 142,47 dengan angka signifikansi lebih kecil dari 0,05. Jadi, perbedaan hasil membaca pemahman antara siswa yang mengikuti model pembelajaran CIRC (Cooperative Integrated Reading and Composition) dengan siswa yang mengikuti model pembelajaran konvensional.

Hipotesis ketiga yang diajukan dalam penelitian ini adalah terdapat terdapat perbedaan kemampuan membaca dan hasil membaca pemahaman antara siswa yang mengikuti model pembelajaran CIRC (Cooperative Integrated Reading and Composition) dengan siswa yang mengikuti model pembelajaran konvensional. Pengujian hipotesis ketiga dengan test of between-subjects effects. ditunjukkan 
dengan harga statistik $F$ sebesar 142,47 dengan angka signifikansi lebih kecil dari 0,05 . Angka signifikansi tersebut lebih kecil dari 0,05. Jadi hasil ini sekaligus menunjukkan bahwa kemampuan membaca dan hasil membaca pemahaman siswa kelas IV SD di Gugus VI Kecamatan Buleleng yang mengikuti Model Pembelajaran CIRC (Cooperative Integrated Reading and Composition) lebih baik dari kelompok siswa yang mengikuti pembelajaran dengan model pembelajaran konvensional.

\section{Pembahasan}

Hasil uji hipotesis I dalam penelitian di dapat nilai $F$ sebesar 98,97 dengan signifikansi pada $<0,05$ sehingga nilai $F$ signifikan yang menyatakan model pembelajaran cooperative integrated reading and composition berbantuan media cerita bergambar berpengaruh terhadap kemampuan membaca, hasil tersebut dikarenakan bahwa pembelajaran dengan model pembelajaran cooperative integrated reading and compotition berbantuan media cerita bergambar lebih baik dalam meningkatkan kemampuan membaca siswa melalui cerita konkrit, dibandingkan dengan model pembelajaran konvensional yang masih memfokuskan pada teacher centre. Membaca bukanlah sekadar menyuarakan lambang-lambang tertulis tanpa mempersoalkan apakah rangkaian kata atau kalimat yang dilafalkan tersebut dipahami atau tidak, melainkan lebih daripada itu. Menurut Burns (dalam Jano 2017) keterampilan berbahasa ada empat, yaitu keterampilan menyimak, berbicara, membaca, dan menulis. Membaca sebagai suatu proses merupakan semua kegiatan dan teknik yang ditempuholeh pembaca yang mengarah pada tujuan melalui tahaptahap tertentu. Menurut (Slavin dalam Ari Surestiani, 2014) Pembelajaran kooperatif tipe Cooperative Integrated Reading and Compotition (CIRC) adalah sebuah program komprehensif atau luas dan lengkap untuk pengajaran membaca dan menulis untuk kelas-kelas tinggi sekolah dasar. Menurut Kautsar (2017) Model
CIRC (Cooperative Integrated Reading and Compotition) adalah model pembelajaran kooperatif yang digunakan dalam pembelajaran bahasa, yakni kemampuan membaca dan menulis tingkat tinggi. Model pembelajaran CIRC (Cooperative Integrated Reading and Compotition) ini termasuk dalam Cooperative Learning dimana dalam pembelajaran ini akan tercipta sebuah interaksi yang lebih luas, yaitu interaksi dan komunikasi yang dilakukan antara guru dengan siswa, siswa dengan siswa, dan siswa dengan guru.

Hasil penelitian di atas didukung oleh penelitian, 1) Ni Putu Yuni Setiawati tahun 2017 dengan judul "Pengaruh Model Pembelajaran CIRC Berbasis Tulisan Eksposisi Terhadap Kemampuan Membaca Intensif Siswa Kelas IV". Hal ini ditunjukkan dari hasil penelitian, bahwa ada perbedaan yang signifikan kemampuan membaca antara kelompok siswa yang belajar menggunakan model pembelajaran CIRC (Cooperative Integrated Reading and Composition) dengan kelompok siswa yang belajar menggunakan model pembelajaran konvensional. Kelompok siswa yang belajar menggunakan model pembelajaran CIRC (Cooperative Integrated Reading and Composition) lebih terlihat kemampuan membaca yang baik, 2) Penelitian Ni Made Yudasmini tahun 2015 dengan judul "Pengaruh Model Pembelajaran CIRC (Cooperative Integrated Reading And Composition) terhadap Minat Baca dan Kemampuan Memahami Bacaan pada Siswa Kelas VI Di Sekolah Dasar Gugus Buruan". Hal ini ditunjukkan dari hasil penelitian, bahwa ada perbedaan yang signifikan minat baca dan kemampuan memahami bacaan antara kelompok siswa yang belajar menggunakan metode pembelajaran CIRC (Cooperative Integrated Reading and Composition) dengan kelompok siswa yang belajar menggunakan model pembelajaran konvensional. Dengan demikian disimpulkan bahwa terdapat perbedaan kemampuan membaca yang signifikan antara kelompok siswa yang dibelajarkan dengan model pembelajaran Cooperative Integrated Reading and 
Compotition berbantuan media cerita bergambar dengan kelompok siswa yang dibelajarkan dengan model konvensional.

Hasil uji hipotesis II dalam penelitian di dapat nilai $F$ sebesar 142,47 dengan signifikansi pada $<0,05$ sehingga nilai $F$ signifikan yang menyatakan model pembelajaran cooperative integrated reading and composition berbantuan media cerita bergambar berpengaruh terhadap hasil membaca pemahaman, hasil tersebut dikarenakan bahwa pembelajaran dengan model pembelajaran cooperative integrated reading and compotition berbantuan media cerita bergambar lebih baik untuk meningkatkan hasil membaca pemahaman siswa melalui tes obyektif, dibandingkan dengan model pembelajaran konvensional yang masih memfokuskan pada teacher centre. Membaca pemahaman adalah pemahaman arti atau maksud dalam suatu bacaan melalui tulisan. Definisi ini sangat menekankan pada dua hal yang pokok dalam membaca, yaitu bahasa itu sendiri dan simbol grafik tulisan yang menyajikan informasi yang berwujud bacaan (Nurhadi dalam Sumira, dkk. 2017). Jadi, seseorang yang melakukan kegiatan membaca pemahaman harus menguasai bahasa atau tulisan yang digunakan dalam bacaan yang dibacanya dan mampu menangkap informasi atau isi bacaan tersebut. Menurut (Slavin dalam Ari Surestiani, 2014) Pembelajaran kooperatif tipe Cooperative Integrated Reading and Compotition (CIRC) adalah sebuah program komprehensif atau luas dan lengkap untuk pengajaran membaca dan menulis untuk kelas-kelas tinggi sekolah dasar. Menurut Kautsar (2017) Model CIRC (Cooperative Integrated Reading and Compotition) adalah model pembelajaran kooperatif yang digunakan dalam pembelajaran bahasa, yakni kemampuan membaca dan menulis tingkat tinggi. Model pembelajaran CIRC (Cooperative Integrated Reading and Compotition) ini termasuk dalam Cooperative Learning dimana dalam pembelajaran ini akan tercipta sebuah interaksi yang lebih luas, yaitu interaksi dan komunikasi yang dilakukan antara guru dengan siswa, siswa dengan siswa, dan siswa dengan guru.

Hasil penelitian di atas didukung oleh penelitian, 1) Ni Made Yudasmini tahun 2015 dengan judul "Pengaruh Model Pembelajaran CIRC (Cooperative Integrated Reading And Composition) terhadap Minat Baca dan Kemampuan Memahami Bacaan pada Siswa Kelas VI Di Sekolah Dasar Gugus Buruan". Adanya perbedaan yang signifikan menunjukkan bahwa Model pembelajaran Model Pembelajaran CIRC (Cooperative Integrated Reading And Composition) berpengaruh secara signifikan terhadap minat baca dan kemampuan memahami bacaan pada siswa kelas VI Di Sekolah Dasar Gugus Buruan. Peneliti menemukan adanya peningkatan minat membaca dan kemampuan memahami bacaan. Dengan demikian disimpulkan bahwa terdapat perbedaan hasil membaca pemahaman yang signifikan antara kelompok siswa yang dibelajarkan dengan model pembelajaran Cooperative Integrated Reading and Compotition berbantuan media cerita bergambar dengan kelompok siswa yang dibelajarkan dengan model konvensional. Penggunaan model pembelajaran Cooperative Integrated Reading and Compotition berbantuan media cerita bergambar dapat menuntun dan mengembangkan kemampuan membaca siswa, sehingga dapat membantu siswa untuk memahami isi bacaan.

Analisis hipotesis III dengan uji manova menunjukkan nilai $F$ sebesar 142,47 dengan signifikansi untuk Pillai's Trace, Wilk's Lambda, Hotelling's Trace, Roy's Largest Root sebesar <0,001, angka ini tentu jauh lebih kecil dari taraf signifikan 0,05, maka $H_{0}$ ditolak dan $H_{1}$ diterima, berdasarkan perhitungan Pillai's Trace, Wilk's Lambda, Hotelling's Trace, Roy's Largest Root menunjukkan bahwa nilai $\mathrm{F}$ lebih besar dari signifikansi, hal tersebut menandakan bahwa terdapat simultan antara kemampuan membaca dan hasil membaca pemahaman yang dipengaruhi oleh model pembelajaran cooperative 
integrated reading and composition berbantuan media cerita bergambar. Hasil tersebut dikarenakan bahwa pembelajaran dengan model pembelajaran cooperative integrated reading and compotition berbantuan media cerita bergambar lebih baik untuk meningkatkan kemampuan membaca siswa melalui cerita konkrit dan hasil membaca pemahaman melalui tes obyektif, dibandingkan dengan model pembelajaran konvensional yang masih memfokuskan pada teacher centre. Membaca pemahaman adalah pemahaman arti atau maksud dalam suatu bacaan melalui tulisan. Definisi ini sangat menekankan pada dua hal yang pokok dalam membaca, yaitu bahasa itu sendiri dan simbol grafik tulisan yang menyajikan informasi yang berwujud bacaan Nurhadi (Sumira, dkk. 2017). Jadi, seseorang yang melakukan kegiatan membaca pemahaman harus menguasai bahasa atau tulisan yang digunakan dalam bacaan yang dibacanya dan mampu menangkap informasi atau isi bacaan tersebut. Untuk dapat memahami isi suatu bahan bacaan dengan baik diperlukan adanya kemampuan membaca pemahaman yang baik pula. Pemahaman merupakan salah satu aspek yang penting dalam kegiatan membaca, sebab pada hakikatnya pemahaman suatu bahan bacaan dapat meningkatkan ketrampilan membaca itu sendiri maupun untuk tujuan tertentu yang hendak dicapai. Jadi, kemampuan membaca dapat diartikan sebagai kemampuan dalam memahami bahan bacaan. Tujuan membaca adalah pemahaman bukan kecepatan (Tarigan, 1986). Menurut Slavin (dalam Ari Surestiani, 2014) Pembelajaran kooperatif tipe Cooperative Integrated Reading and Compotition (CIRC) adalah sebuah program komprehensif atau luas dan lengkap untuk pengajaran membaca dan menulis untuk kelas-kelas tinggi sekolah dasar. Menurut Kautsar (2017) Model CIRC (Cooperative Integrated Reading and Compotition) adalah model pembelajaran kooperatif yang digunakan dalam pembelajaran bahasa, yakni kemampuan membaca dan menulis tingkat tinggi. Model pembelajaran CIRC (Cooperative Integrated Reading and Compotition) ini termasuk dalam Cooperative Learning dimana dalam pembelajaran ini akan tercipta sebuah interaksi yang lebih luas, yaitu interaksi dan komunikasi yang dilakukan antara guru dengan siswa, siswa dengan siswa, dan siswa dengan guru.

Hasil penelitian di atas didukung oleh penelitian, 1) $\mathrm{Ni}$ Made Yudasmini tahun 2015 dengan judul "Pengaruh Model Pembelajaran CIRC (Cooperative Integrated Reading And Composition) terhadap Minat Baca dan Kemampuan Memahami Bacaan pada Siswa Kelas VI Di Sekolah Dasar Gugus Buruan". Adanya perbedaan yang signifikan menunjukkan bahwa Model pembelajaran Model Pembelajaran CIRC (Cooperative Integrated Reading And Composition) berpengaruh secara signifikan terhadap minat baca dan kemampuan memahami bacaan pada siswa kelas VI Di Sekolah Dasar Gugus Buruan. Peneliti menemukan adanya peningkatan minat membaca dan kemampuan memahami bacaan. Dengan demikian secara simultan terdapat perbedaan kemampuan membaca dan hasil membaca pemahaman antara kelompok siswa yang mengikuti model pembelajaran Cooperative Integrated Reading and Compotition berbantuan media cerita bergambar dan kelompok siswa yang mengikuti model pembelajaran konvensional.

\section{PENUTUP \\ Simpulan}

Berdasarkan hasil pengujian hipotesis, maka dapat disimpulkan 1) terdapat perbedaan kemampuan membaca yang signifikan antara kelompok siswa yang dibelajarkan dengan model pembelajaran Cooperative Integrated Reading and Compotition berbantuan media cerita bergambar dengan kelompok siswa yang dibelajarkan model pembelajaran konvensional, 2) terdapat perbedaan hasil membaca pemahaman yang signifikan antara kelompok siswa yang dibelajarkan dengan model pembelajaran Cooperative 
Integrated Reading and Compotition berbantuan media cerita bergambar dengan kelompok siswa yang dibelajarkan model pembelajaran konvensional, 3) terdapat perbedaan kemampuan membaca dan hasil membaca pemahaman yang signifikan antara kelompok siswa yang dibelajarkan dengan model pembelajaran Cooperative Integrated Reading and Compotition berbantuan media cerita bergambar dengan kelompok siswa yang dibelajarkan model pembelajaran konvensional.

\section{Saran-Saran}

Berdasarkan hasil penelitian yang diperoleh, maka dapat diajukan beberapa saran guna meningkatkan kualitas proses pembelajaran, Saran yang dapat disampaikan dalam penelitian ini adalah sebagai berikut.

1) Disarankan kepada guru untuk dapat meneruskan atau menerapkan model pembelajaran Cooperative Integrated Reading and Compotition berbantuan media cerita bergambar pada mata pelajaran lain sehingga dapat meningkatkan hasil belajar siswa, 2) kepada peneliti yang lain disarankan untuk melakukan penelitian pada mata pelajaran lain, dan melakukan penelitian yang lebih mendalam dan meluas pada mata pelajaran Bahasa Indonesia.

\section{DAFTAR RUJUKAN}

Undang-Undang tentang Sistem Pendidikan Nasional. Tersedia pada http://pendis.kemenag.go.id/file/doku men/uuno20th2003ttgsisdiknas.pdf. (diakses tanggal 14 November 2018).

Dantes. 2017. Desain Eksperimen Dan Analisis Data. Singaraja: Undiksha Press.

Jano, 2017. Pengaruh Model Pembelajaran Cooperative Integrated Reading and Composition (CIRC) Terhadap Hasil Belajar Bahasa Indonesia Membaca Pemahaman Ditinjau dari Kemampuan Verbal Siswa SD Kelas V. Universitas Pendidikan Ganesha.
Kautsar. 2017. Penerapan Model Cooperative Integrated Reading And Composition Untuk Meningkatkan Kemampuan Membaca Pada Tema Peristiwa Dalam Kehidupan Siswa Kelas $V$ MIN 40 Aceh Besar. Universitas Islam Negeri Ar-Raniry Darussalam-Banda Aceh.

Setiawati. 2017. Pengaruh Model Pembelajaran CIRC Berbasis Tulisan Eksposisi Terhadap Kemampuan Membaca Intensif Siswa Kelas IV. eJournal PGSD Universitas Pendidikan Ganesha Mimbar PGSD (Vol: 5 No: 2 Tahun: 2017).

Slamet, 2014. Pembelajaran Keterampilan Berbahasa Indonesia. Yogyakarta: Graha IImu.

Slavin. 2008. Cooperative Learning Teori Riset dan Praktik. Bandung: Nusa Media.

Sudarmaji. 2010. Upaya Meingkatkan Kemampuan Apresiasi Cerita Pendek Melalui Penerapan Metode Pembelajaran Cooperative Integrated Reading and Composition (CIRC) pada Siswa Kelas V SD Negeri IV Pulutan Wetan Wuryantoro Wonogiri Tahun Ajaran 200/2010. Jawa Tengah: Universitas Terbuka Wonogiri.

Sugiyono. 2010. Metode Penelitian Pendidikan Pendekatan Kuantitatif, Kualitatif, dan R\&D. Bandung: Alfabeta.

Sumira, dkk. 2017. Pengaruh Metode Scramble terhadap Kemampuan Membaca Pemahaman dan Kecerdasan Interpersonal Siswa SD. Universitas Negeri Jakarta.

Yudasmini. 2015. Pengaruh Model Pembelajaran Circ (Cooperative Integrated Reading And Composition) Terhadap Minat Baca Dan Kemampuan Memahami Bacaan Pada Siswa Kelas Vi D 
Vol.2 No 1, Pebruari 2018

ISSN: 2613-9553

Sekolah Dasar Gugus Buruan. eJournal Program Pascasarjana Universitas Pendidikan Ganesha

Evaluasi Pendidikan (Volume 5, No Program Studi Penelitian dan 